\title{
Serological evidence of association between Helicobacter pylori infection and coronary artery disease
}

\author{
${ }^{1}$ EL-Ageery, S. M., ${ }^{* 1,4}$ Gouda, N. S., ${ }^{2}$ Fawzy, I. M., ${ }^{3}$ Bahy-Eldeen, A., and ${ }^{3}$ Mahmoud, R. \\ ${ }^{1}$ Medical Microbiology and Immunology Department, Faculty of Medicine, Mansoura University, Egypt \\ ${ }^{2}$ Mansoura Central Laboratories, Clinical Pathology Department, Ministry of Health, Egypt \\ ${ }^{3}$ Internal Medicine Department, Faculty of Medicine, Mansoura University, Egypt \\ ${ }^{4}$ Medical Microbiology and Immunology Department, Faculty of Medicine, Northern Border University, \\ Kingdom of Saudi Arabia \\ *Correspondence to: nawalsalama@gmail.com; 00966502933179
}

\begin{abstract}
:
Background: Studies have reported relationship between chronic Helicobacter pylori infection and coronary artery disease (CAD). The cytotoxin-associated gene A product (CagA) is an immunodominant protein which indicates infection with virulent $H$. pylori strains. Significant associations of CagA-positive $H$. pylori strains with coronary artery disorders have been widely reported. $H$. pylori is also known to produce different heat shock proteins (HSPs) which can stimulate the production of specific antibody against microbial proteins and capable of eliciting autoimmune reaction against human tissue expressing HSPs such as vascular endothelial cells. The objectives of this study are to investigate the association between $H$. pylori and CagA with coronary atherosclerosis and CAD, and to determine the possible role of $H$. pylori HSP60 protein in increasing the risk of CAD development. Methods: This study included 70 patients with stable angina and 70 age and gender-matched controls. Each group was evaluated by clinical history, physical examination, cardiac echocardiography (ECHO) and electrocardiography (ECG) with and without exercise. Fasting blood glucose, total cholesterol (TC), low density lipoprotein (LDL), high density lipoprotein (HDL) and triglycerides (TG) were estimated by automated enzymatic methods. H. pylori IgG, CagA IgG and HSP60 IgG were measured by enzyme-linked immunosorbent assay (ELISA) for both groups. Results: The seroprevalence of $H$. pylori infection was high in both groups; $75.7 \%$ in case and $68.6 \%$ in control $(p=0.346)$. Serum IgG levels were significantly higher for CagA $(p=0.028)$ and HSP60 $(p<0.001)$ in cases than in controls. There was significant association between $H$. pylori and CagA IgGs in cases $(p=0.007)$ but no association in controls $(p=0.700)$. Higher HSP60 IgG level was significantly associated with both positive $H$. pylori IgG $(p<0.001)$ and CagA IgG $(p<0.001)$ in cases but no significant association was found with $H$. pylori $(p=0.815)$ or CagA $(p=0.332)$ IgG levels in the control group. Serum values were significantly higher for TC $(p<0.001)$, TG $(p<0.001)$ and LDL $(p=0.004)$ while value for HDL was significantly lower $(p<0.001)$ in $H$. pylori IgG-positive subjects (case and control).

Conclusion: There is serological evidence that $H$. pylori infection may pose a significant risk factor for CAD. Since $H$. pylori can be eliminated by specific treatment, this may be a good preventive approach for CAD.
\end{abstract}

Key words: H. pylori, coronary artery disease, CagA, HSP60, serology.

Received July 23, 2019; Revised October 27, 2019; Accepted October 28, 2019

Copyright 2020 AJCEM Open Access. This article is licensed and distributed under the terms of the Creative Commons Attrition 4.0 International License (http://creativecommmons.org/licenses/by/4.0), which permits unrestricted use, distribution and reproduction in any medium, provided credit is given to the original author(s) and the source.

\section{Preuve sérologique d'association entre l'infection à Helicobacter pylori et la maladie coronarienne}

\author{
${ }^{1}$ EL-Ageery, S. M., ${ }^{* 1,4}$ Gouda, N. S., ${ }^{2}$ Fawzy, I. M., ${ }^{3}$ Bahy-Eldeen, A., et ${ }^{3}$ Mahmoud, R.
}

${ }^{1}$ Département de microbiologie médicale et d'immunologie, Faculté de médecine, Université Mansoura, Égypte

${ }^{2}$ Laboratoires centraux Mansoura, Département de pathologie clinique, Ministère de la santé, Égypte

${ }^{3}$ Département de médecine interne, Faculté de médecine, Université Mansoura, Égypte

${ }^{4}$ Département de microbiologie médicale et d'immunologie, Faculté de médecine, Université Northern Border, 
Royaume d'Arabie saoudite.

*Correspondance à: nawalsalama@gmail.com; 00966502933179

\section{Abstrait:}

Contexte: Des études ont montré un lien entre l'infection chronique à Helicobacter pylori et la maladie coronarienne. Le produit du gène $A$ associé à la cytotoxine (CagA) est une protéine immunodominante qui indique une infection par des souches virulentes de $H$. pylori. Des associations significatives de souches de $H$. pylori CagApositives avec des troubles coronariens ont été largement rapportées. $H$. pylori est également connu pour produire différentes protéines de choc thermique (HSP) capables de stimuler la production d'anticorps spécifiques contre les protéines microbiennes et capables de provoquer une réaction auto-immune contre les HSP exprimant le tissu humain, telles que les cellules endothéliales vasculaires. Les objectifs de cette étude sont d'étudier l'association entre $H$. pylori et CagA avec l'athérosclérose coronarienne et la coronaropathie, et de déterminer le rôle possible de la protéine $H$. pylori HSP60 dans l'augmentation du risque de développement de coronaropathie.

Méthodes: Cette étude a inclus 70 patients présentant une angine de poitrine stable et 70 témoins de même âge et de même sexe. Chaque groupe a été évalué par antécédents cliniques, examen physique, échocardiographie cardiaque $(E C H O)$ et électrocardiographie (ECG) avec et sans exercice. La glycémie à jeun, le cholestérol total $(T C)$, les lipoprotéines de basse densité (LDL), les lipoprotéines de haute densité (HDL) et les triglycérides (TG) ont été estimés par des méthodes enzymatiques automatisées. Les IgG anti-H. pylori, IgG CagA et IgG HSP60 ont été mesurées par dosage immuno-enzymatique (ELISA) pour les deux groupes.

Résultats: La séroprévalence de l'infection à $H$. pylori était élevée dans les deux groupes; $75,7 \%$ en cas et $68,6 \%$ en contrôle $(p=0,346)$. Les taux sériques d'IgG étaient significativement plus élevés pour CagA $(p=0,028)$ et HSP60 $(p<0,001)$ chez les sujets témoins. Il y avait une association significative entre les IgG anti-H. pylori et CagA dans les cas $(p=0,007)$, mais aucune association chez les témoins $(p=0,700)$. Un taux plus élevé d'IgG HSP60 était associé de manière significative à la fois aux IgG positives pour $H$. pylori $(p<0,001)$ et aux IgG antiCagA $(p<0,001)$, mais aucune association significative n'a été constatée avec H. pylori $(p=0,815)$ ou CagA $(p=0,332)$. Taux d'IgG dans le groupe témoin. Les valeurs sériques étaient significativement plus élevées pour le CT $(p<0,001)$, le TG $(p<0,001)$ et le $\operatorname{LDL}(p=0,004)$, tandis que les valeurs pour le HDL étaient significativement plus basses $(p<0,001)$ chez les sujets positifs pour $H$. pylori IgG.

Conclusion: Il existe des preuves sérologiques que l'infection à $H$. pylori peut constituer un facteur de risque significatif de coronaropathie. Étant donné que $H$. pylori peut être éliminé par un traitement spécifique, cela peut constituer une bonne approche préventive pour la coronaropathie.

Mots clés: H. pylori, maladie coronarienne, CagA, HSP60, sérologie.

\section{Introduction:}

Helicobacter pylori infection is one of the most widespread infections worldwide, affecting half the population of the world. The bacterium causes chronic gastritis, peptic ulcer and gastric cancer (1). The infection stimulates both cell mediated and humoral immune system with elevation of basophils and polymorphs (2), and increased concentration of local and systemic vasoactive cytokines (3). These reactions are not restricted to the digestive tract (4) but also involved many extra gastrointestinal manifestations including haematological disorders (idiopathic thrombocytopenic purpura and unexplained iron deficiency anemia), neurological disorders (stroke, Parkinson and Alzheimer's diseases), obesity and skin diseases $(5,6)$.

Several studies have reported relationship between chronic $H$. pylori infection and coronary artery disease (CAD), highlighting its role in the pathogenesis of coronary vascular disorders (7). The cytotoxin-associated gene A (CagA) product is an immunodominant protein which indicates infection with virulent $H$. pylori strains. Some studies have reported significant associations of CagA-positive $H$. pylori strains with coronary artery disorders (8).

Helicobacter pylori have been detected in human atherosclerotic plaques by immunohistochemistry and polymerase chain reaction (9), and particularly in patients undergoing coronary bypass grafting (10). Chronic $H$. pylori infection is believe to induce low-grade constant inflammatory response with release of mediators that causes vascular endothelial damage through recruitment of monocytes and T-lymphocytes to the vascular wall, even in the absence of the pathogen. Therefore, chronic $H$. pylori infection does not only induce coronary atherosclerosis but can activate acute coronary rupture (11).

A variety of systemic effects including atherosclerosis can be induced by chronic infection in several different manners through increasing circulating cytokine (interleukins 1 and 6) production and formation of the acutephase products such as C-reactive protein and white blood cells. Also, chronic infection can stimulate the immune system with production of antibodies against the infecting pathogen (12). Furthermore, pathogens can stimulate proliferation and migration of smooth muscle 
cells, accumulation of lipid, and formation of several pro-coagulants, with inhibition of endothelial cell apoptosis (13).

Heat shock proteins (HSPs) represent well conserved protein families sharing wide sequence homology amongst various species, from bacteria to humans (14). Exposure to stressful stimuli such as sudden increase in temperature, hypoxia, infection, inflammation, mechanical stress, and oxidizing agents can induce or up-regulate production of HSPs (14). These proteins play essential roles in the bacterial growth at different temperatures and protection against a variety of injurious factors (15). H. pylori are known to produce different HSPs that stimulate the production of specific antibodies (16). Due to high sequence homology of HSPS, autoimmune reaction directed against bacterial HSPs as well as human (such as vascular endothelium) HSPs, could occur (17).

The objectives of this study are to; (i) determine association between $H$. pylori and CagA protein with CAD; (ii) investigate the possible role of $H$. pylori in CAD by estimating its specific HSP60 IgG levels in patients with CAD and healthy subjects and (iii) determine association between $H$. pylori and known risk factors for CAD.

\section{Methodology:}

\section{Subjects (case and control)}

This case control study was conducted over a period of six months (January to June 2019), and included 70 patients (cases) with stable angina selected by stratified random sampling among patients admitted to the cardiology unit or attending the cardiology outpatient clinic of Mansoura University Hospital, Egypt. Clinical history, physical examination, cardiac echocardiography (ECHO), and electrocardiography (ECG) with and without exercise, were done for each subject. The cases had signs and symptoms of angina at exercise ECG with more than $2 \mathrm{~mm}$ ST segment depression. The controls were 70 age and gender-matched patients randomly selected from units other than cardiology who had no feature of CAD (negative tread mill test).

\section{Exclusion criteria}

The exclusion criteria for both case and control subjects were; (i) significant kidney insufficiency (creatinine more than $1.5 \mathrm{mg} / \mathrm{dL}$ ), (ii) significant hypothyroidism/hyperthyroidism (serum thyroid stimulating hormone level more than $4.5 \mathrm{IU} / \mathrm{mL}$ or free thyroxine more than $2 \mathrm{ng} / \mathrm{dL}$ ), (iii) significant C-reactive protein elevation (more than $10 \mathrm{mg} / \mathrm{L}$ ) and (iv) persons with any history of intake of antibiotics for $H$. pylori infection during the last 3months.

\section{Ethical approval}

The study was approved by Institutional Review Board of the Faculty of Medicine, Mansoura University, Egypt. All subject participants gave informed consent for the study.

\section{Clinical and laboratory evaluations of case and control subjects}

Subjects in both groups were evaluated for hypertension (indicated by systolic blood pressure $\geq 140 \mathrm{mmHg}$, diastolic blood pressure of $\geq 90 \mathrm{mmHg}$ (or antihypertensive medication), body mass index (BMI), and smoking (patients who had stopped smoking for 10years or less were classified as smokers). Approximately $10 \mathrm{ml}$ of venous blood was collected from each subject with the serum separated and stored in aliquots at $-80^{\circ} \mathrm{C}$ until specific tests were done.

Determination of serum glucose and lipids Fasting blood glucose (FBG), total cholesterol (TC), low density lipoprotein (LDL), high density lipoprotein (HDL) and triglycerides (TG) were measured by enzymatic methods in an automated chemistry analyzer (Toshiba TBA-120 FR, Toshiba Medical Systems, Japan)

\section{Determination of $\boldsymbol{H}$. pylori infection IgG}

The level of serum IgG to $H$. pylori $O$ antigen was determined by a commercial enzyme-linked immunosorbent assay (ELISA) (Euroimmun, Germany). The value of upper limit of normal range for $H$. pylori specific IgG level for the assay kit is 22units/mL.

\section{Determination of $\boldsymbol{H}$. pylori CagA IgG}

The level of serum IgG to $H$. pylori CagA protein was serologically detected by a commercial ELISA assay (Radim Diagnostics, Germany). The value of upper limit of normal range for $H$. pylori CagA specific IgG levels for the assay kit is 15 units $/ \mathrm{mL}$.

\section{Determination of $\boldsymbol{H}$. pylori HSP60 IgG}

The level of serum IgG to $H$. pylori HSP60 was serologically detected by a commercial ELISA assay (Elabscience Biotechnology, China). The detection range of the kit was from $78.13-5000 \mathrm{pg} / \mathrm{mL}$.

\section{Statistical analysis}

Statistical analysis was performed with the Statistical Package for the Social Sciences software version 17.0 (SPSS Inc., Chicago, IL, USA). The association between two variables 
was evaluated using Chi-square or Fisher Exact tests for categorical variables and Student $t$ tests for continuous variables, with $p<0.05$ considered significant.

\section{Results:}

This study was conducted on 70 patients who had stable angina, with mean age of 58.9 years, and 70 controls with a comparable mean age of 57.7 years $(p=0.426)$. The cases (36 males, 34 females) were gender-matched with the controls (40 males, 30 females) $(p=0.497)$. The mean BMI of cases and controls were 30.4 and 29.8 respectively $(p=0.251)$. There were no significant differrences between the case and control subjects regarding history of smoking $(p=0.319)$, hypertension $(p=0.122)$, diabetes mellitus $(p=0.231)$ or fasting blood glucose $(p=0.074)$.

The prevalence of $H$. pylori infection was $75.7 \%$ in the case and $68.6 \%$ in control subjects $(p=0.346)$. On the other hand, CagA IgG $(p=0.028)$ and HSP60 IgG $(p<0.001)$ values were significantly higher in cases than in controls (Table 1 ).

Table 1: Comparison of demographic and clinical data of case and control subjects

\begin{tabular}{|c|c|c|c|c|}
\hline Parameter & & Control $(n=70)$ & Case $(n=70)$ & $p$ value \\
\hline Age (years) & Mean \pm SD & $57.7 \pm 9.2$ & $58.9 \pm 9.6$ & 0.426 \\
\hline Age range (years) & & $41-72$ & $45-75$ & \\
\hline \multicolumn{5}{|l|}{ Gender } \\
\hline Male & n (\%) & $40(57.1)$ & $36(51.4)$ & 0.497 \\
\hline Female & $\mathrm{n}(\%)$ & $30(42.9)$ & $34(48.6)$ & \\
\hline BMI (kg/m2) & Mean \pm SD & $29.8 \pm 3.0$ & $30.4 \pm 3.5$ & 0.251 \\
\hline Smoking & $\mathrm{n}(\%)$ & $14(20.0)$ & $19(27.1)$ & 0.319 \\
\hline DM & n (\%) & $14(20.0)$ & $22(31.4)$ & 0.122 \\
\hline $\mathrm{FBG}(\mathrm{mg} / \mathrm{dL})$ & Median (range) & $107.5(78-256)$ & $110.5(85-350)$ & 0.074 \\
\hline Hypertension & n (\%) & $26(37.1)$ & $33(47.1)$ & 0.231 \\
\hline Helicobacter pylori IgG & $\mathrm{n}(\%)$ & $48(68.6)$ & $53(75.7)$ & 0.346 \\
\hline CagA IgG & $\mathrm{n}(\%)$ & $31(44.3)$ & $44(62.9)$ & $0.028^{*}$ \\
\hline HSP60 IgG & Median (range) & 839 (550-4837) & 3365 (1187-5298) & $<0.001 *$ \\
\hline
\end{tabular}

* = significant difference 
Table 2: Association of CagA IgG with Helicobacter pylori IgG in case and control subjects

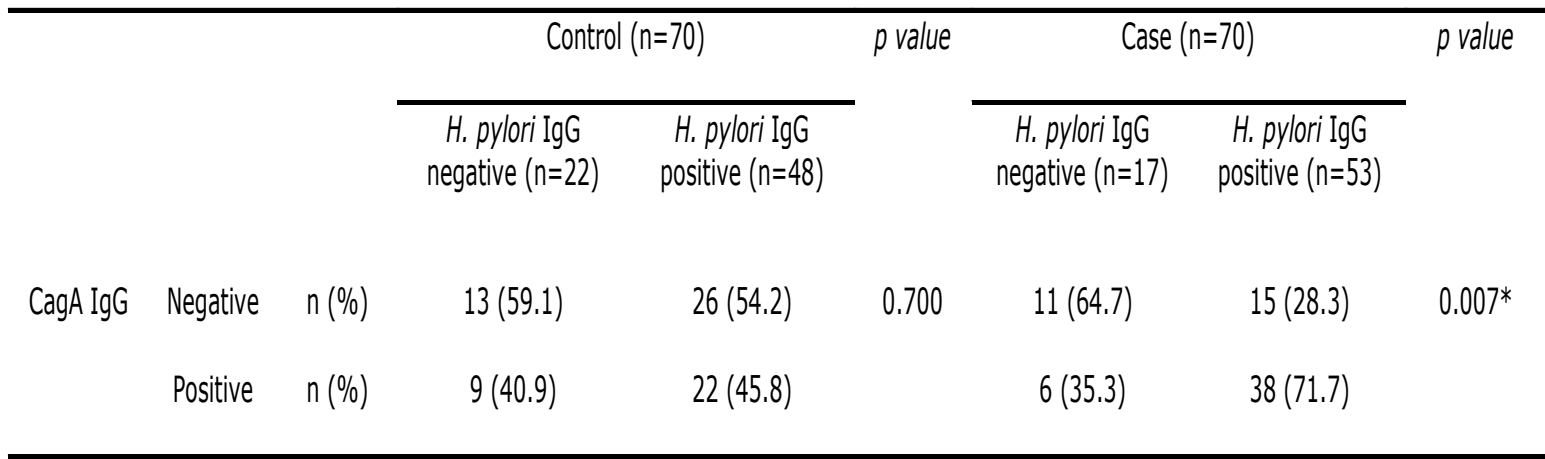

$*=$ significant difference

口CagA IgG Negative — CagA IgG Positive

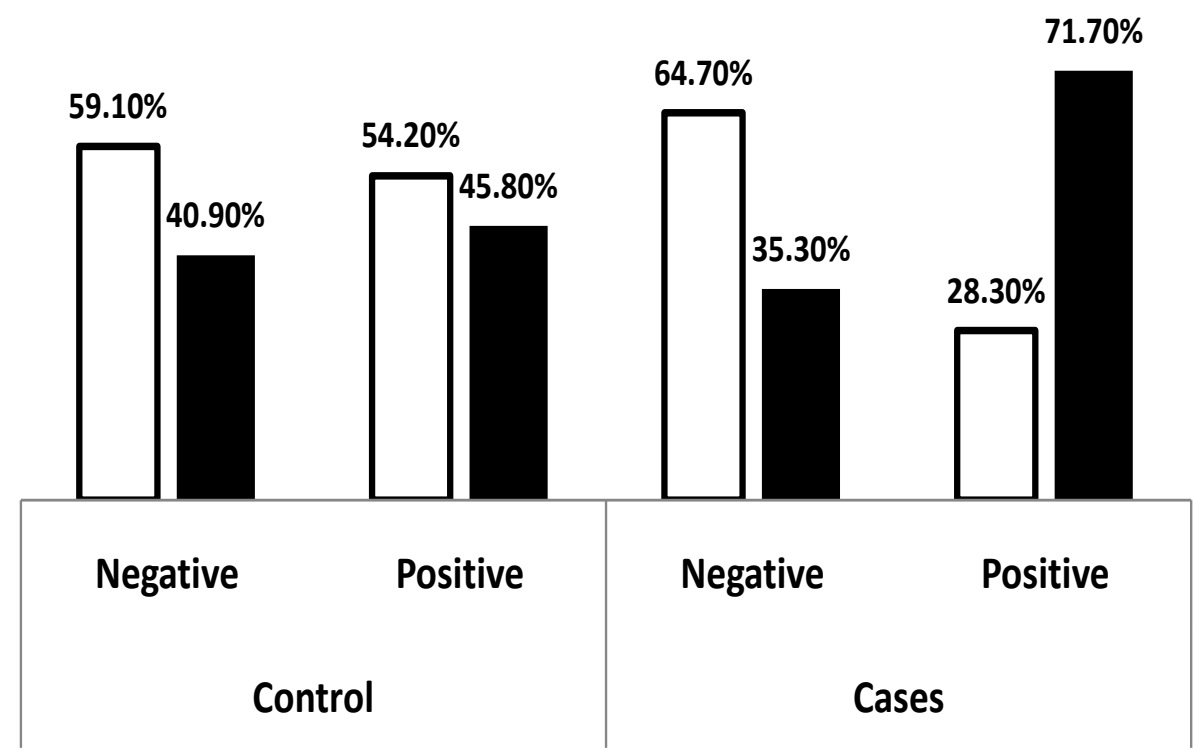

H. pylori IgG

Fig. 1: Association of CagA IgG with H. pylori IgG in case and control subjects

There was significant association of $H$. pylori and CagA IgGs in the case $(p=0.007)$ but no such association in the control $(p=0.700)$ (Table 2 and Fig 1$)$. Higher antiHSP60 antibodies level was significantly associated with positive $H$. pylori IgG $(p<0.001)$ and CagA IgG $(p<0.001)$ in the case but no significant association was found with $H$. pylori IgG $(p=0.815)$ or CagA IgG $(p=0.332$ ) in the control group (Table 3, Figs 2 and 3 ). The serum levels were significantly higher for TC $(p<0.001)$, TG $(p<0.001)$, and LDL $(p=0.004)$ in $H$. pylori IgG-positive than $H$. pylori IgG-negative subjects (case and control) while HDL value was significantly lower $(p<0.001)$ in $H$. pylori IgG-positive subjects (Table 4). 
Table 3: Association of HPS60 IgG with H. pylori and Cag A IgGs in case and control subjects

\begin{tabular}{|c|c|c|c|c|c|c|c|}
\hline & & \multicolumn{2}{|c|}{ Control $(n=70)$} & \multirow[t]{2}{*}{$p$ value } & \multicolumn{2}{|c|}{ Case $(n=70)$} & \multirow[t]{2}{*}{$p$ value } \\
\hline & & $\begin{array}{c}\text { H. pylori IgG } \\
\text { negative }(n=22)\end{array}$ & $\begin{array}{c}\text { H. pylori IgG } \\
\text { positive }(n=48)\end{array}$ & & $\begin{array}{c}H . \text { pylori IgG } \\
\text { negative }(n=17)\end{array}$ & $\begin{array}{c}H . \text { pylori IgG } \\
\text { positive }(n=53)\end{array}$ & \\
\hline \multirow[t]{3}{*}{ HSP60 IgG } & Median & 962.5 & 794 & 0.815 & 2698 & 3658 & $<0.001^{*}$ \\
\hline & Range & $550-4398$ & $550-4837$ & & $1187-3827$ & $1187-5298$ & \\
\hline & & $\begin{array}{c}\text { CagA IgG } \\
\text { negative }(n=39)\end{array}$ & $\begin{array}{c}\text { CagA IgG } \\
\text { positive }(n=31)\end{array}$ & $p$ value & $\begin{array}{c}\text { CagA IgG } \\
\text { negative }(n=26)\end{array}$ & $\begin{array}{c}\text { CagA IgG } \\
\text { positive }(n=43)\end{array}$ & $p$ value \\
\hline \multirow[t]{2}{*}{ HSP60 IgG } & Median & 839 & 1445 & 0.332 & 2765 & 3876 & $<0.001^{*}$ \\
\hline & Range & $550-4398$ & $560-4837$ & & $1187-3265$ & $1576-5298$ & \\
\hline
\end{tabular}

* = significance difference

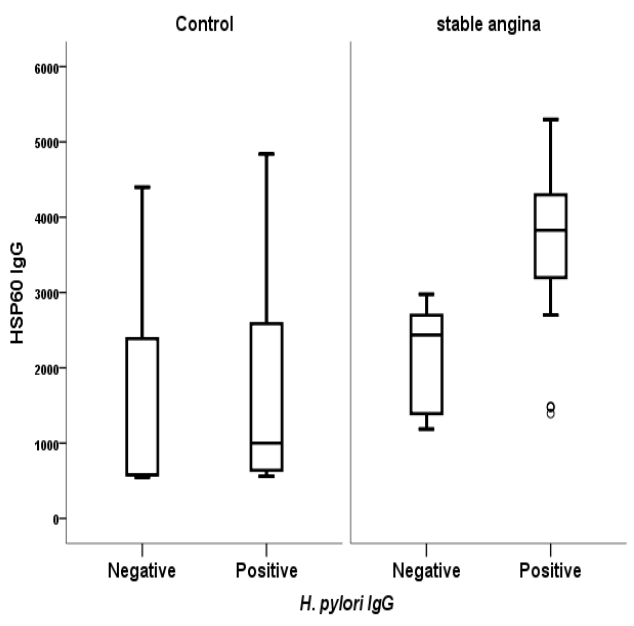

Fig. 2: Association of HPS60 IgG with H. pylori IgG in case and control subjects

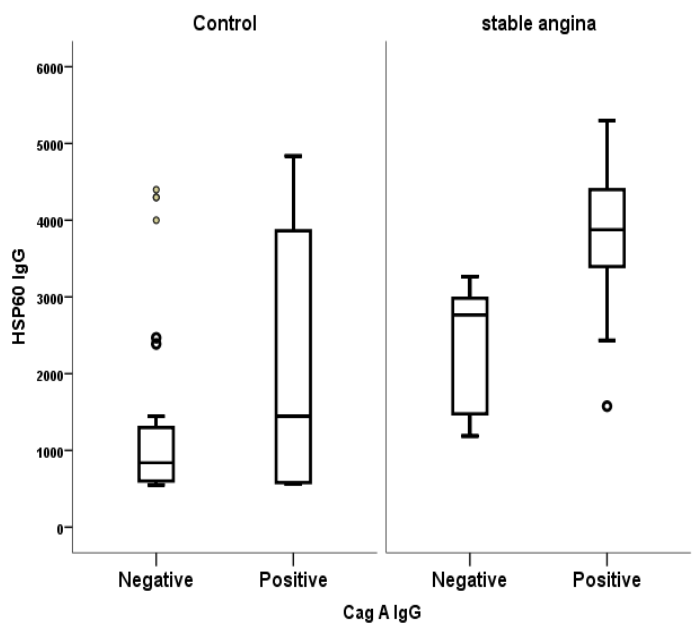

Fig 3: Association of HPS60 IgG with CagA IgG in case and control subjects

Table 4: Association of Helicobacter pylori IgG with lipid profiles in case and control subjects

\begin{tabular}{|c|c|c|c|c|c|c|c|c|c|c|}
\hline \multirow[t]{3}{*}{ Parameter } & \multicolumn{5}{|c|}{ Control $(n=70)$} & \multicolumn{5}{|c|}{ Case $(n=70)$} \\
\hline & \multicolumn{2}{|c|}{$\begin{array}{c}\text { H. pylori IgG } \\
\text { negative } \\
(n=22)\end{array}$} & \multicolumn{2}{|c|}{$\begin{array}{c}\text { H. pylori IgG } \\
\text { positive }(n=48)\end{array}$} & \multirow[t]{2}{*}{$p$ value } & \multicolumn{2}{|c|}{$\begin{array}{c}H . \text { pylori IgG } \\
\text { negative }(\mathrm{n}=17)\end{array}$} & \multicolumn{2}{|c|}{$\begin{array}{c}H . \text { pylori IgG } \\
\text { positive }(n=53)\end{array}$} & \multirow[t]{2}{*}{$p$ value } \\
\hline & median & range & median & range & & median & range & median & range & \\
\hline $\mathrm{TG}(\mathrm{mg} / \mathrm{dL})$ & 50 & $42-76$ & 125 & $76-234$ & $<0.001$ & 49 & $42-102$ & 130 & $50-145$ & $<0.001$ \\
\hline $\mathrm{TC}(\mathrm{mg} / \mathrm{dL})$ & 116 & $\begin{array}{l}94- \\
195\end{array}$ & 160 & $94-220$ & $<0.001$ & 129 & $50-166$ & 182 & $135-330$ & $<0.001$ \\
\hline $\mathrm{LDL}(\mathrm{mg} / \mathrm{dL})$ & 23.5 & $\begin{array}{l}12- \\
154\end{array}$ & 75.5 & $16-165$ & $<0.001$ & 200 & $160-272$ & 230 & $124-340$ & 0.004 \\
\hline $\mathrm{HDL}(\mathrm{mg} / \mathrm{dL})$ & 55 & $52-59$ & 50 & $44-52$ & $<0.001$ & 55 & $48-57$ & 47 & $38-55$ & $<0.001$ \\
\hline
\end{tabular}




\section{Discussion:}

CAD has been considered one of the extra gastrointestinal diseases associated with $H$. pylori infection (18). In this study designed to determine, by serology, association between $H$. pylori and CAD, the cases were carefully matched for age, gender and important risk factors for CAD such as history of smoking, hypertension and diabetes mellitus, with the controls. In our study, H. pylori IgG was high in both case and control groups $(p=0.346)$. Studies done on the association between $H$. pylori infection and cardiovascular diseases have been mostly carried out with the serological $H$. pylori IgG test because it is rapid, inexp- ensive and non-invasive $(19,20)$. However, there have been contradictory reports between serology and occurrence of CAD. While some researchers have reported non-significant association between $H$. pylori seropositivity and $\operatorname{CAD}(21,22)$, others have reported sign- ificant association $(19,20)$. These conflicting reports may be explained by the fact that antibody testing cannot differentiate recent and past infection (23). Therefore, serological test is usually performed to study only association between the occurrence of $H$. pylori infection and CAD (19).

In this study, CagA IgG was significantly detected in cases more than controls $(p=0.028)$, and there was significant association of $H$. pylori and Cag A IgGs in the cases $(p=0.007)$ but not in the controls $(p=0.700)$. It has been reported that patients with CAD are more prone to infection by CagA positive $H$. pylori strains with more vigorous clinical manifestations (24). This may be due to the exaggerated inflammatory reaction in CagApositive $H$. pylori infection from increased systemic levels of interleukin (IL)-1 $\beta$, IL-6, IL8 and tumour necrosis factor-alpha (TNF-a), which tend to exert injurious damage to the vascular endothelial cells (11). In addition, elevated levels of thrombin factor and prothrombin subunits $\mathrm{F} 1+2$ in patients with both CAD and CagA positive $H$. pylori strains have been reported (25). Moreover, antibodies against CagA show cross-reactivity with vascular wall antigens, providing a potential role of CagA in vascular wall inflammation (26).

The serum HSP60 IgG level in our study was significantly higher in cases than in controls $(p<0.001)$ and higher anti-HSP60 antibodies level was significantly associated with both $H$. pylori and CagA IgGs positivity in the case but no such significant association in the control group. This may suggests an association between $H$. pylori HSP60 and development of CAD. Consistent with the hypothesis of Wick and coworkers (27), atherosclerosis can be associated with high levels of HSP antibodies because of an autoimmune response directed against endothelial tissue expressing high levels of HSP in response to traumatic stimuli such as local infections, cytokines, elevated LDL, or other stressful conditions. Another explanation is that both bacterial toxic metabolites and the concomitant inflammatory response can change the epithelial HSP such that immune tolerance to self HSP is lost, with production of autoantibodies which cross-react with $H$. pylori HSPs (11). Latif et al., (28) found a strong similarity between HSP60 and heavy chain of cardiac myosin, therefore, cross-reaction between related epitopes could result in autoimmunity.

In our study, $H$. pylori IgG-positive subjects had significantly elevated TG, TC and LDL levels and significantly lower HDL level than those with $H$. pylori IgG-negative ones. Some researchers have reported that chronic $H$. pylori infection changes the lipid profile. Rahman et al., (29) and Lee et al., (30) reported significantly lower levels of HDL in patients with $H$. pylori infection with and without CAD. Jia et al., (31) reported that $H$. pylori infection may lower HDL levels with predisposition to coronary atherosclerosis. Kim et al., (32) also reported that LDL cholesterol level was significantly higher in $H$. pylori infected patients, and increasing $H$. pylori severity increased LDL levels, which is the most important risk factor for atherosclerosis. Therefore, atherogenic lipid (elevated LDL and decreased HDL) profile has been reported in $H$. pylori infected compared to un-infected patients (33). However, other researchers have reported that lipid profile was not affected by $H$. pylori infection and therefore not considered as a risk factor for CAD (34).

\section{Conclusion:}

There is serological evidence that $H$. pylori infection may pose a significant risk factor for CAD. Since $H$. pylori can be eliminated by specific treatment, this may be a good preventive approach for CAD.

\section{Conflicts of interest:}

Authors declare non financial conflicts of interest in this study 


\section{References:}

1- Huang, J. Q., Zheng, G. F., Sumanac, K., Irvine, E. J., and Hunt, R. H. Meta-analysis of the relationship between CagA seropositivity and gastric cancer. Gastroenterol. 2003; 125 (6): 1636- 1644.

2- Graham, D. Y., Osato, M. S., Olson, C. A., Zhang, J., and Figura, N. Effect of $H$. pylori infection and CagA status on leukocyte counts and liver function tests: extra-gastric manifestations of $H$. pylori infection. Helicobacter. 1998; 3: 174- 178.

3- Perri, F., Clemente, R., Festa, V., De Ambrosio, C. C., Quitadamo, M., Fusillo, M., Grossi, E., and Andriulli, A. Serum tumour necrosis factor-alpha is increased in patients with Helicobacter pylori infection and CagA antibodies. Ital J Gastroenterol Hepatol 1999; 31: 290- 294.

4- Patel, P., Mendall, M. A., Khulusi, S., Northfield, T. C., and Strachan, D. P. Helicobacter pylori infection in childhood: risk factors and effect on growth. BMJ. 1994; 309: 1119- 1123.

5- Tan, H. J., and Goh, K. L. Extragastrointestinal manifestations of Helicobacter pylori infection: facts or myth? A critical review. J Digest Dis. 2012; 13 (7): 342- 349.

6- Suzuki, H., Franceschi, F., Nishizawa, T., and Gasbarrini, A. Extragastric manifestations of Helicobacter pylori infection. Helicobacter. 2011; 16 (1): 65- 69.

7- Gunn, M., Stephens, J. C., Thompson, J. R. Rathbone, B. J., and Samani, N. J. Significant association of CagA positive Helicobacter pylori strains with risk of premature myocardial infarction. Heart. 2000; 84: 267-271.

8- Sun, J., Rangan, P., Bhat, S. S., and Liu, L. A meta-analysis of the association between Helicobacter pylori infection and risk of coronary heart disease from published prospective studies. Helicobacter. 2016; 21 (1): 11- 23.

9- Ameriso, S. F., Fridman, E. A., Leiguarda, R. C., and Sevlever, G. E. Detection of Helicobacter pylori in human carotid atherosclerotic plaques. Stroke. 2001; 32: 385-391.

10- Izadi, M., Fazel, M., and Sharubandi, S. H. Helicobacter species in the atherosclerotic plaques of patients with coronary artery disease. Cardiovasc Pathol. 2012; 21 (4): 307-311.

11- Lenzi, C., Palazzuoli, A., Giordano, N., et al.. $H$. pylori infection and systemic antibodies to CagA and heat shock protein 60 in patients with coronary heart disease. World J Gastroenterol. 2006; 12 (48): 7815- 7820.

12- Epstein, S. E., Zhou, Y. F., and Zhu, J. Infection and atherosclerosis: emerging mechanistic paradigms. Circulation. 1999; 100: e20-e28.

13- Epstein, S. E. The multiple mechanisms by which infection may contribute to atherosclerosis development and course. Circ Res. 2002;90:2-4.

14- Xu, Q., and Wick, G. The role of heat shock proteins in protection and pathophysiology of the arterial wall. Mol Med Today. 1996; 2: 372- 379.

15- Winfield, J. B., and Jarjour, W. N. Stress proteins, autoimmunity, and autoimmune disease. Curr Top Microbiol Immunol. 1991; 167: 161- 189.

16- Suerbaum, S., Thiberge, J. M., Kansau, I., Ferrero, R. L., and Labigne, A. Helicobacter pylori HSPA-HSPB heat-shock gene cluster: nucleotide sequence, expression, putative function and immunogenicity. Mol Microbiol. 1994; 14: 959974.

17- Pérez-Pérez, G. I., Thiberge, J. M., Labigne, A., and Blaser, M. J. Relationship of immune response to heat-shock protein $A$ and characteristics of
Helicobacter pylori-infected patients. J Infect Dis. 1996; 174: 1046- 1050

18- Jin, S. W., Her, S. H., and Lee, J. M. The association between current Helicobacter pylori infection and coronary artery disease. Korean J Intern Med. 2007; 22 (3): 152- 156

19- Park, M. J, Choi, S. H, Kim, D. Kang, S. J., Chung, S. J., and Choi, S. Y. Association between Helicobacter pylori seropositivity and the coronary artery calcium score in a screening population. Gut Liver. 2011; 5: 321- 327.

20- Schottker, B., Adamu, M. A., Weck, M. N., Muller, $\mathrm{H}$., and Brenner, H. Helicobacter pylori infection, chronic atrophic gastritis and major cardiovascular events: a population-based cohort study. Atherosclerosis. 2012; 220: 569- 574.

21- Ikeda, A., Iso, H., Sasazuki, S., Inoue, M., Tsugane, S., and Group, J. S. The combination of Helicobacter pylori and cytotoxin-associated geneA seropositivity in relation to the risk of myocardial infarction in middle aged Japanese: The Japan Public Health Center-based study. Atherosclerosis. 2013; 230: 67- 72.

22- Rogha, M., Nikvarz, M., Pourmoghaddas, Z., Shirneshan, K., Dadkhah, D, and Pourmoghaddas, M. Is Helicobacter pylori infection a risk factor for coronary heart disease? ARYA Atherosclerosis. 2012; 8: 5- 8 .

23- Atkinson, N. S., and Braden, B. Helicobacter pylori infection: diagnostic strategies in primary diagnosis and after therapy. Dig Dis Sci. 2016; 61: 19- 24.

24- Figura, N., Palazzuoli, A., Faglia, S., et al.. Infection by CagA-positive Helicobacter pylori strains in patients with ischemic heart disease: prevalence and association with exercise-induced electrocardiographic abnormalities. Dig Dis Sci. 2002; 47: 831- 836.

25- Khodaii, Z., Vakili, H., Ghaderian, S. M., Najar, R. A., and Panah, A. S. Association of Helicobacter pylori infection with acute myocardial infarction. Coronary Artery Dis 2011; 22: 6-11.

26- Franceschi, F., Sepulveda, A. R., Gasbarrini, A. Pola, P., Silveri, N. G., Gasbarrini, G., Graham, D. Y., and Genta, R. M. Cross-reactivity of anti-CagA antibodies with vascular wall antigens: possible pathogenic link between Helicobacter pylori infection and atherosclerosis. Circulation. 2002; 106: $430-434$

27- Wick, G., Knoflach, M., Kind, M., Henderson, B., and Bernhard, D. Heat shock proteins and stress in atherosclerosis. Autoimmun Rev. 2004; 3 Supp 1: S30-S31

28- Latif, N., Taylor, P. M., Khan, M. A., Yacoub, M. H., and Dunn, M. J. The expression of heat shock protein 60 in patients with dilated cardiomyopathy. Basic Res Cardiol. 1999; 94: 112- 119.

29- Rahman, M. A., Cope, M. B., Sarker, S. A., Garvey, W. T., Chaudhury, H. S., and Khaled, M. A. Helicobacter pylori Infection and inflammation: implication for the pathophysiology of diabetes and coronary heart disease in Asian Indians. J Life Sci 2009; 1: 45-50.

30- Lee, M., Baek, H., Park, J. S., et al. Current Helicobacter pylori infection is significantly associated with subclinical coronary atherosclerosis in healthy subjects: A cross-sectional study. PLoS One. 2018; 13 (3): e0193646.

31- Jia, E. Z., Zhao, F. J., and Hao, B. Helicobacter pylori infection is associated with decreased serum levels of high density lipoprotein, but not with the severity of coronary atherosclerosis. Lipids Health Dis. 2009; 8: 59.

32- Kim, H. L., Jeon, H. H., Park, I. Y., Choi, J. M. Kang, J. S., and Min, K. W. Helicobacter pylori 
infection is associated with elevated low density lipoprotein cholesterol levels in elderly Koreans. Korean Med Sci. 2011; 26: 654- 658.

33- Kanbay, M., Gür, G., Yücel, M., Yilmaz, U., and Boyacioğlu, S. Does eradication of Helicobacter pylori infection help normalize serum lipid and CRP levels? Dig Dis Sci 2005; 50: 1228-1231
34- Vafaeimanesh, J., Hejazi, S. F., Damanpak, V., Vahedian, M., Sattari, M., and Seyyedmajidi, M. Association of Helicobacter pylori infection with coronary artery disease: is Helicobacter pylori a risk factor? Sci. World J. 2014; 16: Article ID 516354,6 pages. 